Idealcoolismo: um olhar psicanalitico sobre o alcoolismo Antonio Alves Xavier e Emir Tomazelli (Orgs.). São Paulo: Casa do Psicólogo, 2012, 284 págs.

\title{
Idealcoolismo: uma contribuição psicanalítica ao tratamento teórico-clínico do alcoolismo
}

Vera Lúcia Lamas Vidueiros*

A Coleção Clínica Psicanalítica, dirigida por Flávio Carvalho Ferraz e editada pela Casa do Psicólogo, nos oferece mais uma expressiva contribuição para a compreensão do psiquismo humano, especialmente nesta obra, que trata de um tema bastante controverso: o alcoolismo, estudado, pesquisado e reconstruído pelas mentes e mãos dos psicanalistas, Antonio Alves Xavier e Emir Tomazelli.

Reconstrução que se inicia pelo título do livro: Idealcoolismo. O termo criado pelos autores para mais bem elucidar os fenômenos desse campo trabalhoso, provoca nosso pensamento. Efetivamente, provoca e atualiza.

Idealcoolismo propõe, para início de conversa, a participação da psique humana e da sua história emocional na construção da "ideal-adicção do álcool", inserindo-a na história e na cultura, e se dirige para além das questões bioquímicas da dependência tão referenciadas nos dias de hoje.

\footnotetext{
* Psicanalista com atendimento em consultório particular (São Paulo, SP, Br).
} 
Os autores nos apresentam que a relação estabelecida entre o indivíduo e o álcool, nos estados de alcoolismo, é da ordem da idealização, por isso o termo idealcoolismo, no sentido de que o álcool se torna a ilusão do divino ou o próprio divino que o protege da realidade e da sua humanidade frustrante em troca de sua oferenda, seu corpo e sua alma. Isto é, o estado emocional que o álcool provoca por meio de sua ingestão alcoólatra não recreativa leva-o a um tal estado de afastamento das angústias e de sobrevoo sobre os limites humanos, que funda uma "religião"de veneração, fidelidade e entrega. Daí a intensa impregnação do álcool na vida do alcoólatra: viver com um deus, viver como deus, viver fusionado a ele, sobreviver à realidade que teima em nos desamparar ou à humanidade que é ontologicamente limitada.

Esse homem infantil e infantilizado que vorazmente e narcisicamente (narcisismo de morte) se entrega fielmente ao deus-álcool, torna-se um só com ele, evitando a inveja e a frustração que a realidade provoca, e o afastamento de sua frágil condição nos remete à gênese do idealcoolismo.

Embasados substancialmente nas formulações de Freud, somadas às contribuições de Klein, Steiner, Brenman e Rosemberg, os autores nos remetem às primeiras relações no desenvolvimento humano, onde a solução oral perdura ao longo da vida do indivíduo como uma forma privilegiada para o afastamento das angústias. A conjuntura nos apresenta uma relação mãe-bebê bastante comprometida, quer seja por componentes ativos de ansiedade, idealização e inveja, quer seja especialmente pela presença maciça da pulsão de morte. Acresce-se a essa situação, a ausência de um pai amoroso e protetor. $\mathrm{O}$ encaminhamento sucessivo dessa relação inicial mostra a formação de uma organização patológica com seus elementos de estreiteza mental e masoquismo mortífero, isto é, a predominância do princípio de Nirvana e do princípio de prazer sobre a realidade, da dor como alívio e excitação, da ilusão de completude e de não falta.

A excessiva presença da pulsão de morte transforma o masoquismo primário e a tolerância da dor para o crescimento em tolerância prazerosa da dor, em acúmulo de investimento em vez de descarga; a inveja de não ser o ideal e de não ter o idealizado transforma-se em arrogância e onipotência e, portanto, converge a mente para a estreiteza mental e para o assassinato do outro. Sobram ressentimentos e rancor, mágoas de um passado, mas combustíveis importantes para a repetição na parceria fusionada com o álcool. Formula-se uma relação com o mundo destituída do próprio mundo e, portanto, do triste, do belo e da responsabilidade. Por isso, um humano menos humanizado, isto é, possuidor de uma história de vida onde falha a construção de uma psique melhor equipada e inserida na cultura.

Por fim, o livro nos apresenta três encontros. Primeiro, o encontro da técnica psicanalítica com o paciente idealcoolista, paciente este que nos provoca certa esquiva, dúvidas e desesperança a respeito de uma possibilidade eficaz de seu 
tratamento. Encontro que produz uma contribuição: a introdução, na relação com o paciente, da técnica que os autores denominam como choque de humanidade ou o "chum", que visa humanizar o inumanizado, ou seja, apresentar ao paciente, as questões sobre o triste e o belo, o absurdo e o não absurdo, a responsabilidade, a morte. E ainda, que é possível viver bem a vida humana, apesar de humana. Exatamente aquilo que ofende o alcoólatra e o ataca - sentir-se humano - é o que deve ser ministrado como fármaco na relação, relação esta que por si só já está assentada na realidade e humanidade do par. O choque de humanidade orienta-nos no árduo trabalho de caminhar com esses pacientes para a reconstrução de uma mente, desta vez capacitada a pensar e privilegiar a vida, a reconhecer o humano potente, porém, limitado. Segundo, a apresentação de um caso clínico, o encontro entre o analista e seu paciente idealcoolista, onde podemos apreciar os conceitos, a técnica e as reflexões apontadas pelos autores. Mas também podemos apreciar a trama emocional de ambos, as dores, as questões, as dificuldades do percurso.

Terceiro e último, o encontro com a instituição mais tradicional e extensa na recuperação de alcoólatras, os Alcoólicos Anônimos (AA). Um encontro entre os psicanalistas autores e sua disponibilidade de compreender o programa de recuperação expresso pelos doze passos dos AAs.

\section{Vera Lúcia Lamas Vidueiros}

Psicanalista pelo Instituto Sedes Sapientiae (São Paulo, SP, Br) e Psicóloga pela Pontifícia

Universidade Católica de São Paulo - PUC-SP (São Paulo, SP, Br).

Rua Cardoso de Almeida, 313/133 - Perdizes

05013-001 São Paulo, SP, Br

e-mail: veralamasvidueiros@gmail.com 